\title{
ANALISIS FAKTOR INTERNAL DAN EKSTERNAL YANG MEMPENGARUHI DANA PIHAK KETIGA BANK SYARIAH DI INDONESIA
}

\author{
Bisri dan Herlin Widasiwi Setianingrum \\ Dosen Tetap Universitas Bina Sarana Informatika \\ bisri.bir@bsi.ac.id, herlin.hww@bsi.ac.id
}

\begin{abstract}
This study aims to determine the external and internal factors that affect deposits of Islamic banking. Whereas internal factors in this study is Islamic bank deposits profit sharing and the external factors are interest rate of conventional banks deposits and Indonesia Composite Index (IDX composite). The analysis used is cointegration and error correction model (ECM). As a result, interest rate of conventional banks deposits, Islamic bank deposits profit sharing and IDX composite are stationary at difference 1, then proceed with seeing cointegration that occurs in these variables. The results show cointegration in these variables which is indicated by the ADF value of -3,6951. Furthermore, estimation is done by ECM which gives significant results with ECT values of -0.3326. This shows that in the short and long term, Islamic bank deposits profit sharing, interest rate of conventional banks deposits and IDX composite have a significant effect on the Islamic banks deposits. With the adjusted $R$-squared value of 0.6032 or $60.32 \%$, it can be seen that the independent variables included in the model are good enough.
\end{abstract}

Keywords: cointegration, error correction model and stationary.

\section{PENDAHULUAN}

Perkembangan bisnis

perbankan syariah pada beberapa tahun ini sedang memasuki masa suram. Pertumbuhan aset yang sempat mencapai 49 persen pada 2013 belum bisa terulang lagi pada tahun-tahun sesudahnya.

Turunnya pertumbuhan perbankan syariah, tidak hanya terjadi dari sisi aset, namun juga pembiayaan dan dana pihak ketiga (DPK). Pertumbuhan DPK bank syariah tahun
2015 hanya sebesar 5,8\% dari tahun sebelumnya, kemudian pada tahun 2016 dan tahun 2017 masing-masing sebesar $17,28 \%$ dan $16,48 \%$. Pertumbuhan tersebut menurun drastis dari tahun-tahun sebelumnya, dimana pertumbuhan DPK bank syariah sebesar 34,14\% pada tahun 2011, sebesar 21,49\% pada tahun 2012 dan sebesar 19,62\% pada tahun 2013 .

Beberapa penelitian mengenai dana pihak ketiga bank syariah telah banyak dilakukan, salah satunya 
penelitian yang dilakukan oleh Harfiah, dkk (2016) yang menganalisis faktor yang berpengaruh terhadap tingkat bagi hasil dana pihak ketiga bank syariah. Hasil penelitian tersebut menemukan bahwa Suku Bunga Deposito secara signifikan berpengaruh kepada tingkat bagi hasil dana pihak ketiga.

Dalam penelitian lain yang dilakukan oleh Al-Arif dan Hanifah (2017) menyimpulkan bahwa Tingkat Bagi Hasil Deposito Bank Syariah berpengaruh terhadap volume deposito pada Bank Umum Syariah. Hal ini senada dengan penelitian Kasri (2010) yang menemukan bahwa dana pihak ketiga bank syariah dipengaruhi oleh tingkat suku bunga bank konvensional.

Namun tidak demikian dengan penelitian yang dilakukan oleh Novianto dan Djumilah Hadiwidjojo (2013) yang menemukan bahwa tingkat bagi hasil tidak berpengaruh terhadap deposito mudharabah. Hubungan yang terbentuk antara tingkat bagi hasil dan deposito mudharabah adalah hubungan yang tidak searah karena koefisien regresi yang didapatkan adalah negatif.

Maka, berdasarkan uraian singkat di atas, penelitian ini bertujuan untuk mengetahui faktor internal dan eksternal yang berpengaruh kepada keputusan masyarakat deposan di Indonesia dalam memilih bank syariah atau bank konvensional. Analisa dilakukan dengan melihat hubungan perkembangan dana pihak ketiga di perbankan syariah terhadap faktorfaktor yang mempengaruhi seperti: tingkat bunga deposito bank, tingkat imbal hasil deposito bank syariah, dan IHSG. IHSG dimasukkan dalam penelitian ini karena peneliti ingin melihat apakah pasar modal ikut mempengaruhi pilihan masyarakat dalam menempatkan dananya di bank syariah.

Hal ini menarik, karena melihat fenomena perkembangan bank syariah di Indonesia yang notabene mayoritas muslim terbesar di dunia. Jika dihubungkan dengan peningkatan ekonomi yang pesat pada periode 2009-2013 yang mendorong perkembangan di sektor keuangan khususnya perbankan dan pasar modal. Perkembangan ekonomi yang otomatis meningkatkan kesejahteraan masyarakat tentu saja sedikit banyak mengubah pola hidup masyarakat indonesia. Dengan meningkatnya pendapatan masyarakat memberikan 
kesempatan masyarakat untuk dengan unit usaha syariat adalah unit menyimpan dananya dananya baik dalam bentuk tabungan ataupun kerja di kantor pusat bank konvensional yang berfungsi sebagai deposito di bank. Dalah hal ini kantor induk dari kantor cabang syariah penelitian ini akan menganaisis apakah pilihan masyarakat Indonesia untuk (Rivai dan Arifin, 2010).

Sedangkan menurut UU Nomor menempatkan dananya di bank syariah dipengaruhi oleh faktor internal bank itu sendiri yaitu tingkat imbal hasil atau juga dipengaruhi oleh faktor eksternal bank syariah berupa tingkat bunga bank konvensional ataupun IHSG sebagai representasi pesaing bank syariah dalam menarik dana masyarakat Indonesia.

\subsection{Bank Syariah}

Menurut ketentuan yang tercantum di dalam Peraturan Bank Indonesia nomor 2/8/PBI/2000, pasal 1, bank syariah adalah "bank umum sebagaimana yang dimaksud dalam Undang-Undang nomor 7 tahun 1992 perbankan dan telah diubah dengan Undang-Undang nomor 10 tahun 1998 yang melakukan kegiatan usaha berdasarkan prinsip syariat Islam, termasuk unit usaha syariah dan kantor cabang bank asing yang melakukan kegiatan usaha berdasarkan prinsip syariat Islam. Adapun yang dimaksud

\subsection{Pengertian Dana Pihak Ketiga}

Menurut Kasmir (2012) "pengertian sumber dana bank adalah usaha bank dalam menghimpun dana dari masyarakat". Perolehan dana ini tergantung dari bank itu sendiri, apakah dari simpanan masyarakat atau dari lembaga lainnya. Hal ini sesuai dengan fungsi bank bahwa bank adalah lembaga keuangan dimana kegiatan sehari-harinya bergerak dalam bidang keuangan, maka sumber-sumber dana bank juga tidak terlepas dari bidang keuangan itu sendiri. Untuk menopang kegiatan bank sebagai penjual atau 
memberikan pinjaman, bank harus terlebih dahulu membeli uang atau menghimpun dana sehingga dari selisih bunga tersebut bank memperoleh keuntungan.

Dana pihak ketiga (simpanan) berdasarkan UU Perbankan No. 10 tahun 1998 adalah dana yang dipercayakan oleh masyarakat kepada bank berdasarkan perjanjian penyimpanan dana dalam bentuk giro, deposito, sertifikat deposito, tabungan, dan bentuk lainnya (Rivai, 2007).

Menurut Ismail, dana pihak ketiga biasanya lebih dikenal dengan dana masyarakat, merupakan dana yang dihimpun oleh bank yang berasal dari masyarakat dalam arti luas, meliputi masyarakat individu, maupun badan usaha (Ismail, 2011).

Pentingnya sumber dana dari masyarakat luas, disebabkan sumber dana dari masyarakat luas merupakan sumber dana yang paling utama bagi bank. Sumber dana yang disebut juga sumber dana pihak ketiga ini disamping mudah untuk mencarinya juga tersedia banyak di masyarakat. Kemudian persayaratan untuk mencarinya juga tidak sulit (Kasmir, 2014).

\subsection{Pengertian Suku Bunga Deposito}

Suku bunga juga berarti penghasilan yang diperoleh oleh orangorang yang memberikan kelebihan uangnya atau surplus spending unit untuk digunakan sementara waktu oleh orang-orang yang membutuhkan dan menggunakan uang tersebut untuk menutupi kekurangannya atau deficitspending units (Judisseno, 2005). Suku bunga adalah biaya pinjaman atau harga yang dibayarkan untuk dana pinjaman tersebut (biasanya dinyatakan sebagai persentase per tahun) (Mishkin, 2008).

Menurut Dermawan (2008), Suku bunga yang berlaku di pasar adalah tingkat keuntungan yang diisyaratkan investor pada suatu obligasi. Tinggi rendahnya tingkat keuntungan yang disyaratkan pada obligasi ini tergantung pada risiko kegagalan obligasi yang diperkirakan oleh investor.

Kemudian Mahardjo Kuncoro dan Suhardjono (2011) mengemukakan bahwa suku bunga deposito, terdiri dari suku bunga (counter) yaitu suku bunga yang tercantum pada papan pengumuman masing-masing bank atau dimedia cetak dan suku negosiasi, suku 
negosiasi diberikan kepada nasabahnasabah besar dengan maksud agar dengan kelebihan suku bunga tersebut mau menyimpan di bank yang bersangkutan.

Besarnya suku bunga deposito ditetapkan oleh rapat ALCO (Asset and Liabilities Committee) setiap periode tertentu yang disesuaikan dengan perkembangan pasar dan kebutuhan dana bank yang bersangkutan (Kuncoro, 2011).

\subsection{IHSG}

Indeks harga adalah suatu angka yang digunakan untuk membandingkan suatu peristiwa dibandingkan dengan suatu peristiwa lainnya. Angka Indeks Harga Saham adalah angka - angka yang menjadi ukuran situasi pasar modal, yang dapat digunakan untuk membandingkan peristiwa dan sebagai alat analisis. Indeks Harga Saham Gabungan adalah suatu nilai yang digunakan untuk mengukur kinerja gabungan seluruh saham yang tercatat di bursa efek. Maksud dari gabungan seluruh saham ini adalah kinerja saham yang dimasukkan dalam perhitungan seluruh saham yang tercatat di bursa tersebut (Sunariyah, 2011).
Menurut Sunariyah (2011) Indeks harga saham gabungan menggambarkan suatu rangkaian informasi historis mengenai pergerakan harga saham gabungan seluruh saham, sampai pada tanggal tertentu.

Sedangkan Anoraga dan Pakarti (2008) menjelaskan bahwa IHSG merupakan indeks yang menunjukkan pergerakan harga saham secara umum yang tercatat di bursa efek yang menjadi acuan tentang perkembangan kegiatan di pasar modal. IHSG ini bisa digunakan untuk menilai situasi pasar secara umum atau mengukur apakah harga saham mengalami kenaikan atau penurunan. IHSG juga melibatkan seluruh harga saham yang tercatat di bursa.

IHSG BEI atau JSX CSPI merupakan IHSG yang dikeluarkan oleh BEI. IHSG BEI ini mengambil hari dasar pada tanggal 10 Agustus 1982 dan mengikutsertakan semua saham yang tercatat di BEI. IHSG BEI diperkenalkan pertama kali pada tanggal 01 April 1983 yang digunakan sebagai indikator untuk memantau pergerakan saham. Indeks ini mencakup semua saham biasa maupun saham preferen di BEI. 
1.5 Imbal Hasil Deposito Bank Syariah

Mawardi

menerjemahkan profit distribution sebagai distribusi hasil usaha dan distribusi pendapatan. Bagi hasil (Sholihin, 2010) adalah suatu sistem yang meliputi pembagian hasil usaha antara pemodal dan pengelola dana pembagian hasil usaha. (Ghozali, 2007): Bagi Hasil (Syirkah) Syirkah adalah suatu sistem yang meliputi tata cara pembagian hasil usaha antara penyedia dana dengan pengelola dana. Pembagian hasil usaha ini dapat terjadi antara bank dengan penyimpan dana, maupun antara bank dengan nasabah penerima dana. Bentuk produk yang berdasarkan prinsip ini adalah mudharabah dan musyarakah.

\section{METODOLOGI PENELITIAN}

\subsection{Metode Penelitian}

Metode penelitian yang digunakan oleh penulis adalah berupa penelitian kuantitatif dengan metode kausal. Penelitian kausal adalah penelitian untuk mengetahui pengaruh satu atau lebih variabel (independent variables) terhadap variabel tertentu (dependent variables). Penelitian ini memerlukan pengujian hipotesis dengan statistik (Sugiyono: 2012).

\subsection{Metode Pengumpulan Sampel}

Perkembangan perbankan syariah di Indonesia sungguh mengagumkan oleh karena itu penelitian ini bermaksud melakukan investigasi terhadap perkembangan bank syariah di Indonesia dalam hal ini untuk meneliti variabel-variabel yang mempengaruhi dana pihak ketiga (DPK) bank syariah di Indonesia. Bank syariah yang dimaksud disini adalah bank yang menurut Peraturan Bank Indonesia beroperasi dan memberikan pelayanan jasa perbankan atas dasar prinsip syariah di Indonesia. Adapun periode penelitian yang dilakukan mencakup periode tahun 2003-2008.

Untuk menjawab pertanyaan penelitian lebih jauh mengenai variabel-variabel yang mempengaruhi DPK perbankan syariah dilakukan studi empiris terhadap perbankan syariah di Indonesia. Dengan memperhatikan pertumbuhan asset bank syariah yang begitu cepat yang didukung pertumbuhan jumlah bank yang melayani transaksi berdasarkan syariah, baik yang berupa Bank Umum Syariah, 
Unit Usaha Syariah, maupun BPR Syariah maka penulis menggunakan data dari publikasi laporan keuangan perbankan syariah nasional yang dilaporkan oleh Otoritas Jasa Keuangan dalam bentuk Statistik Perbankan Syariah periode Desember 2013 sampai dengan Desember 2017. Data yang dijadikan sampel berupa data bulanan selama periode tersebut.

\subsection{Metode Pengumpulan Data}

Data yang baik merupakan dasar penelitian yang baik dan selanjutnya akan menghasilkan penelitian yang cukup akurat dalam melihat suatu fenomena. Data secara garis besar digolongkan kedalam data primer dan sekunder. Dalam penelitian ini penulis menggunakan data sekunder yang biasanya berupa bukti, catatan atau laporan historis yang telah tersusun dalam arsip (data dokumenter) yang dipublikasikan dan yang tidak dipublikasikan (Indriantono dan Supomo, 2013). Adapun data sekunder yang dikumpulkan dalam penelitian ini antara lain, data Statistik Perbankan Syariah yang dipublikasikan oleh OJK dan publikasi data statistik ekonomi oleh Badan Pusat Statistik tentang variabel-variabel makroekonomi. Datadata ini dikumpulkan dengan periode bulanan selama periode penelitian.

\subsection{Metode Analisis}

Dalam beberapa hal, teori-teori ekonomi dan keuangan mengindikasikan adanya kointegrasi antara dua variabel tertentu. Misalnya saja ada kecenderungan pergerakan bersama harga saham dan pergerakan besaran dividen yang dibagikan, meskipun pergerakan bersama harga saham dan pergerakan besaran dividen yang dibagikan masing-masing bisa merupakan random walk. Kointegrasi terjadi apabila dijumpai dua variabel random yang masing-masing merupakan random walk (tidak stasioner), tetapi bila keduanya diregresi kombinasi linearnya menjadi stasioner (Nachrowi D. Nachrowi: 2006).

Apabila kointegrasi digunakan untuk menganalisis keseimbangan jangka panjang maka untuk menganalisis tingkat keseimbangan jangka pendek, penelitian ini menggunakan analisa dengan pendekatan Error Correction Model (ECM), yaitu suatu teknik untuk 
mengoreksi ketidakseimbangan jangka pendek menuju pada keseimbangan jangka panjang. Karena metode ECM merupakan metode yang paling sesuai untuk mengoreksi ketidakseimbangan yang terjadi dalam jangka pendek jika variabel-variabel penelitian berkointegrasi atau dalam keseimbangan jangka panjang (Ronny Salomo M: 2007). Secara bertahap dan lebih rinci analisa data dalam penelitian ini diuraikan sebagai berikut:

\section{Stasioneritas}

Dalam berbagai

studi ekonometrika, data time series sangat banyak digunakan. Namun dibalik pentingnya data tersebut, ternyata data time series 'menyimpan' banyak permasalahan, salah satunya adalah otokorelasi. Otokorelasi ini merupakan penyebab yang mengakibatkan data menjadi tidak stasioner, sehingga bila data distasionerkan maka otokorelasi akan hilang dengan sendirinya, karena metode transformasi data untuk membuat data yang tidak stasioner menjadi stasioner sama dengan transformasi data untuk menghilangkan otokorelasi.
Sekumpulan data dapat dinyatakan stasioner jika nilai rata-rata dan varians dari data time series tersebut tidak mengalami perubahan secara sistematik sepanjang waktu atau konstan (Nachrowi D. Nachrowi: 2006). Ada dua macam pengujian secara formal untuk menentukan stasioneritas data yaitu, korelogram dan unit root test. Dalam penelitian ini penulis mengunakan metode unit root test yang diperkenalkan oleh David dickey dan Wayne Fuller, atau lazim disebut Augmented Dickey Fuller Test. Secara umum formulasinya sebagai berikut:

$$
\begin{aligned}
& \Delta Y_{t}=\beta_{1}+\beta_{2 t}+\delta Y_{t-1}+\alpha_{1} \Delta Y_{t-1}+\alpha_{2} \Delta \\
& Y_{t-2}+\ldots . .+\alpha_{m} \Delta Y_{t-m}+\varepsilon_{t}
\end{aligned}
$$

Atau dapat ditulis dengan:

$\Delta Y_{t}=\beta_{1}+\beta_{2 t}+\delta Y_{t-1}+\alpha_{i} \sum_{i=1}^{m} \Delta Y_{t-1}+$ $\varepsilon_{t}$

Dimana $\mathrm{m}=$ panjang lag yang digunakan. Berdasarkan model tersebut kita dapat memilih tiga model yang akan digunakan untuk melakukan Uji ADF, yaitu Model dengan intercept dan tren sebagaimana model di atas.

Model yang hanya intercept saja, yaitu: 


$$
\Delta Y_{t}=\beta_{1}+\delta Y_{t-1}+\alpha_{i} \sum_{i=1}^{m} \Delta Y_{t-1}+\varepsilon_{t}
$$

Model tanpa intercept dan trend, yaitu:

$$
\Delta Y_{t}=\delta Y_{t-1}+\alpha_{i} \sum_{i=1}^{m} \Delta Y_{t-1}+\varepsilon_{t}
$$

Bila hasil uji menyatakan data tidak stasioner maka dilakukan transformasi dengan pembedaan (difference).

\section{Kointegrasi}

Pengujian kointegrasi dengan menggunakan Uji Engle-Granger atau Uji Augmented Engle-granger dapat dilakukan dengan tahapan berikut:

a. Estimasi model regresi

b. Hitung Residualnya

c. Jika residualnya stasioner berarti regresi tersebut merupakan regresi kointegrasi

\section{Error Correction Model (ECM)}

Setelah terbukti variabelvariabel penelitian terkointegrasi, atau dengan kata lain mempunyai hubungan atau keseimbangan jangka panjang. Bagaimana jangka pendeknya? Sangat mungkin terjadi ketidakseimbangan. Oleh karena itu $\mu_{\mathrm{t}}$ dapat juga disebut dengan kesalahan keseimbangan (equilibrium error). Besaran inilah yang akan digunakan untuk menghubungkan perilaku variabelvariabel penelitian dalam jangka pendek dan nilai-nilainya dalam jangka panjang.

Teknik untuk melakukan koreksi ketidakseimbangan jangka pendek menuju keseimbangan jangka panjang disebut Error Correction Model (ECM), dengan model secara umum dapat ditulis

$\Delta Y=a_{0}+{ }_{a 1} \Delta X+a 2 \mu_{t-1}+\varepsilon_{t}$

$\mu_{\mathrm{t}-1}$ adalah error kointegrasi lag 1 , atau secara matematis dapat dituliskan sebagai berikut:

$\mu_{t-1}=Y_{t-1}-\beta_{0}-\beta_{1} X_{t-1}$

sehingga dari model tersebut terlihat bahwa hubungan perubahan $\mathrm{X}$ terhadap $\mathrm{Y}$ dalam jangka panjang akan diseimbangkan oleh error sebelumnya. Dalam persamaan di atas, $\Delta X$ menggambarkan gangguan jangka pendek dari $\mathrm{Y}$, dan error kointegrasi merupakan penyesuai menuju keseimbangan jangka panjang. Dengan demikian, jika koefisien a signifikan, maka koefisien tersebut akan menjadi penyesuaian bila terjadi fluktuasi variabel-variabel yang diamati menyimpang dari hubungan jangka panjangnya. 


\subsection{Rancangan Uji Hipotesis}

Pertama setiap data variabel penelitian diuji dengan uji ADF untuk melihat apakah data-data tersebut stasioner atau tidak? Uji ADF ini dilakukan dengan menggunakan bantuan software Eviews 7. Dengan bantuan software ini akan tersaji tabel yang didalamnya memuat hasil analisis dengan metode ADF. Pada output terlihat nilai uji $\mathrm{ADF}$ dan nilai kritis dengan level keyakinan dari 1\%, 5\% dan $10 \%$. Untuk memutuskan apakah data stasioner atau tidak, maka dibandingkan hasil output tersebut. Jika nilai absolut uji ADF lebih kecil daripada nilai absolut nilai kritis maka dapat diambil kesimpulan bahwa data menghadapi masalah unit root atau data tidak stasioner. Jika data tidak stasioner maka dilakukan transformasi data untuk menstasionerkan data dengan cara pembedaan (difference).

Setelah itu dilakukan uji kointegrasi yang juga menggunakan bantuan software Eview 7. Dari hasil analisis output kointegrasi dengan Eview akan terdapat tulisan yang menyatakan apakah terjadi kointegrasi atau tidak antar variabel-variabel penelitian pada tingkat kepercayaan 1\%, 5\% dan $10 \%$.
Atau dapat dilihat dengan membandingkan nilai trace statistik dengan nilai kritis. Jika nilai trace statistik lebih besar dari nilai kritis maka dapat diambil kesimpulan bahwa terjadi kointegrasi, tetapi sebaliknya apabila nilai trace statistik lebih kecil dari nilai kritis maka dapat diambil kesimpulan tidak terjadi kointegrasi.

ECM juga dapat dianalisis dengan bantuan software Eview 7. Dengan melihat pada nilai signifikansi resid01. Jika nilai signifikansinya lebih besar dari level kepercayaan maka model ECM yang digunakan tidak valid. Tetapi sebaliknya jika nilai signifikansinya lebih kecil dari level kepercayaan maka model ECM yang digunakan dianggap valid.

\section{HASIL DAN PEMBAHASAN}

\section{Uji Stasioneritas Data}

Stasioner merupakan suatu kondisi data time series yang jika rata-rata, varian dan covarian dari peubah-peubah tersebut seluruhnya tidak dipengaruhi oleh waktu (Juanda dan Junaidi, 2012). Metode pengujian stasioneritas dan akar unit yang akan digunakan disini adalah metode Augmented Dickey Fuller (ADF). Nonstationary seri akan 
menciptakan kondisi spurious jangka panjang (cointegration

regression.

Tabel

Uji Stasioneritas Data

\begin{tabular}{lllll}
\hline Variabel & \multicolumn{4}{c}{ Uji Akar Unit } \\
\cline { 2 - 5 } & \multicolumn{2}{c}{ Level } & \multicolumn{1}{c}{$1^{\text {st }}$ Difference } \\
\cline { 2 - 5 } & ADF & Prob & ADF & Prob \\
\hline DPK & $-2,4950$ & 0,1219 & $-13,2015$ & 0,0000 \\
\hline IHD & $-1,7445$ & 0,4040 & $-7,8963$ & 0,0000 \\
\hline BUNGA & $-1,1498$ & 0,6902 & $-7,4182$ & 0,0000 \\
\hline IHSG & $-0,2701$ & 0,9226 & $-6,4575$ & 0,0000 \\
\hline
\end{tabular}

Berdasarkan Tabel dapat

diketahui bahwa seluruh variabel tidak stasioner pada derajat level, namun telah stasioner pada tingkat first difference dengan level $1 \%$ untuk variabel dana pihak ketiga (DPK) dengan nilai t-statistik -13,2015, imbal hasil deposito (IHD) dengan nilai tstatistik -7,8963, bunga deposito (BUNGA) dengan nilai t-statistik 7,4182 dan indeks harga saham gabungan (IHSG) nilai t-statistik 6,4575 .

\section{Uji kointegrasi}

Setelah mengetahui bahwa data tidak stasioner, maka langkah selanjutnya adalah melakukan identifikasi apakah data terkointegrasi. Untuk itu diperlukan uji kointegrasi. Uji kointegrasi digunakan untuk memberi indikasi awal bahwa model yang digunakan memiliki hubungan relation).

Hasil uji kointegrasi didapatkan dengan membentuk residual yang diperoleh dengan cara meregresikan variabel independen terhadap variabel dependen secara OLS. Residual tersebut harus stasioner pada tingkat level untuk dapat dikatakan memiliki kointegrasi. Hasil estimasi menunjukkan bahwa variabel bunga deposito (BUNGA) memiliki nilai tstatistik sebesar 4.045090. Hasil ini berarti hubungan yang terbentuk antara bunga deposito (BUNGA) dan dana pihak ketiga (DPK) adalah hubungan yang searah karena koefisien regresi yang didapatkan adalah positif. Hasil estimasi juga menunjukkan bahwa nilai $t$-statistik variabel produk bunga deposito (BUNGA) yaitu 4.045090> dari nilai $t$-tabel yaitu 0,681 . Dengan demikian, variabel bunga deposito (BUNGA) berpengaruh signifikan terhadap dana pihak ketiga (DPK).

Variabel imbal hasil deposito (IHD) memiliki nilai tstatistik sebesar 2,1249. Hasil ini berarti hubungan yang terbentuk antara imbal hasil deposito (IHD) dan dana pihak ketiga (DPK) 
adalah hubungan yang tidak searah karena koefisien regresi yang didapatkan adalah negatif. Hasil estimasi juga menunjukkan bahwa nilai $t$-statistik variabel imbal hasil deposito (IHD) yaitu $-2,1249$ berada pada daerah penerimaan Ha. Dengan demikian, variabel imbal hasil deposito (IHD) berpengaruh signifikan terhadap dana pihak ketiga (DPK).

Variabel indeks harga saham gabungan (IHSG) memiliki nilai $t$-statistik sebesar -0.34436. Hasil ini berarti hubungan yang terbentuk antara indeks harga saham gabungan (IHSG) dan dana pihak ketiga (DPK) adalah hubungan yang searah karena koefisien regresi yang didapatkan adalah positif. Hasil estimasi juga menunjukkan bahwa nilai $t$-statistik variabel indeks harga saham gabungan (IHSG) yaitu $2,4088>$ dari nilai $t$-tabel yaitu 0,681 . Dengan demikian, variabel indeks harga saham gabungan (IHSG) berpengaruh signifikan terhadap dana pihak ketiga (DPK).

Kemudian dari residual yang dibentuk dilakukan uji stasioneritas dengan hasil penghitungannya dapat dilihat pada tabel 2. Di bawah ini.
Tabel

Uji Stasioneritas Residual

Null Hypothesis: ECT has a unit root

Exogenous: Constant

Lag Length: 0 (Automatic - based on SIC, maxlag=10)

\begin{tabular}{|c|c|c|c|}
\hline & & t-Statistic & Prob.* \\
\hline $\begin{array}{l}\text { Augmented Dickey- } \\
\text { statistic }\end{array}$ & Fuller test & -3.695153 & 0.0066 \\
\hline \multirow[t]{2}{*}{ Test critical values: } & $\begin{array}{l}1 \% \text { level } \\
5 \% \text { level }\end{array}$ & $\begin{array}{l}-3.546099 \\
-2.911730\end{array}$ & \\
\hline & $10 \%$ level & -2.593551 & \\
\hline
\end{tabular}

pada tabel di atas, didapatkan bahwa residual stasioner pada data level yang terlihat dari nilai t-statistik yang signifikan pada nilai kritis 5\% (Prob 0.0066). Dengan demikian dapat dikatakan bahwa data tersebut terkointegrasi.

\section{Error Correction Model}

Setelah hasil pengujian data-data penelitian yang menunjukan data-data tersebut telah terkointegrasi, maka pengujian ECM dapat dilakukan dengan persamaan sebagai berikut:

$\triangle D P K_{t}=\beta_{0}+\beta_{1} \Delta B U N G A_{t}+$ $\beta_{2} \Delta I H D_{t}+\beta_{3} \Delta I H S G_{t}+E C T_{t-1}$

Dimana :

DPK = Dana Pihak Ketiga Bank Syariah

BUNGA = Bunga Deposito Bank Umum 
IHD = Imbal Hasil Deposito

Bank Syariah

IHSG = Indeks Harga Saham

Gabungan

ECT $=$ Error Correction Term

Tabel

Uji Error Correction Model

Dependent Variable: D(DPK)

Method: Least Squares

Date: 11/12/18 Time: 09:11

Sample (adjusted): 2013M02 2017M12

Included observations: 59 after adjustments

\begin{tabular}{|c|c|c|c|c|}
\hline Variable & Coefficient & Std. Eптоr & t-Statistic & Prob. \\
\hline D(BUNGA) & $2.21 E+15$ & $3.09 \mathrm{E}+14$ & 5.692507 & 0.0000 \\
\hline $\mathrm{D}(\mathrm{IHD})$ & $-1.88 \mathrm{E}+15$ & $3.47 \mathrm{E}+14$ & -5.434174 & 0.0000 \\
\hline $\mathrm{D}(\mathrm{IHSG})$ & $2.00 \mathrm{E}+10$ & $2.39 \mathrm{E}+10$ & 0.837033 & 0.4063 \\
\hline ECT(-1) & -0.332570 & 0.106802 & -3.113888 & 0.0030 \\
\hline C & $-6.99 \mathrm{E}+11$ & $4.15 \mathrm{E}+12$ & -0.168597 & 0.8667 \\
\hline R-squared & 0.630556 & Mean dependent var & & 3152.338 \\
\hline Adjusted R-squared & 0.603190 & S.D. dependent var & & $4.94 \mathrm{E}+13$ \\
\hline S.E. of regression & $3.11 \mathrm{E}+13$ & Akaike info criterion & & 65.05843 \\
\hline Sum squared resid & $5.24 \mathrm{E}+28$ & Schwarz criterion & & 65.23449 \\
\hline Log likelihood & -1914.224 & Hannan-Quinn criter. & & 65.12716 \\
\hline F-statistic & 23.04141 & Durbin-Watson stat & & 1.799382 \\
\hline
\end{tabular}

Dari tabel di atas menunjukkan bahwa nilai koefisien ECT pada model tersebut signifikan dan bertanda negatif untuk estimasi dana pihak ketiga (DPK). Hasil estimasi ECM di atas memperlihatkan bahwa dalam jangka pendek maupun jangka panjang variabel yang digunakan dalam kajian ini berpengaruh secara signifikan terhadap Jumlah dana pihak ketiga. Dengan nilai adjusted $R$-squared sebesar 0.630556 atau $63,06 \%$ dapat dikatakan bahwa jenis variabel bebas yang dimasukkan dalam model sudah cukup baik, sebab hanya kurang dari sekitar 37\% keragaman variabel terikat yang dipengaruhi oleh variabel bebas di luar model.

Hasil estimasi di atas menggambarkan bahwa dalam jangka pendek perubahan bunga deposito dan indeks harga gabungan mempunyai pengaruh yang signifikan dan positif terhadap dana pihak ketiga, ceteris paribus. Demikian pula halnya dengan pendapatan imbal hasil deposito yang memiliki pengaruh yang signifikan dan negatif terhadap dana pihak ketiga.

Akhirnya berdasarkan persamaan jangka pendek tersebut dengan menggunakan metode ECM menghasilkan koefisien ECT. Koefisien ini mengukur respon regressand setiap periode yang menyimpang dari keseimbangan. Menurut Widarjono (2007) koefisien koreksi ketidakseimbangan ECT dalam bentuk nilai absolut menjelaskan seberapa cepat waktu diperlukan untuk mendapatkan nilai keseimbangan. Nilai koefisien ECT sebesar 0,3325 mempunyai makna bahwa perbedaan antara dana pihak ketiga dengan nilai keseimbangannya sebesar 33,25 persen yang akan disesuaikan dalam waktu 1 bulan. 


\section{KESIMPULAN}

Berdasarkan hasil analisis dan pembahasan penelitian ini maka dapat diambil kesimpulan bahwa masyarakat dalam menempatkan dana pada bank syariah tidak hanya dipengaruhi oleh motif memperoleh keuntungan. Semangat untuk saling tolongmenolong/tabarru' menjadi alasan lain untuk menempatkan dana pada bank syariah. Perkembangan dana pihak ketiga perbankan syariah sangat terpengaruh oleh keadaan pasar modal nasional. Hal ini dibuktikan dengan temuan bahwa dana pihak ketiga perbankan syariah dipengaruhi oleh IHSG secara positif yang artinya dana pihak ketiga perbankan syariah akan meningkat seiring terjadinya peningkatan perdagangan pasar modal yang ditandai dengan meningkatnya IHSG. Sedangkan kenaikan bunga deposito bank umum konvensional tidak menyebabkan penurunan dana pihak ketiga perbankan syariah malah yang terjadi sebaliknya.

\section{REFERENSI}

Al-Arif, M. Nur Rianto dan Hanifah. 2017. "Detereminan Deposito Bank Umum Syariah: Model Regresi Panel. Jurnal
Ekonomi Kuantitatif terapan, Vol. 10 No 2. Februari.

Anoraga dan Pakarti. (2008). Pengantar Pasar Modal. Jakarta : PT. Rineka Cipta

Dermawan, Sjahrial. (2008). Manajemen Keuangan Lanjutan, Edisi Kedua, Mitra Wacana Media, Jakarta

Ghozali, Imam. (2007). Manajemen Resiko Perbankan. Semarang: BPUNDIP.

Harfiah, Laila Mugi, Atiek Sri Purwati dan Permata Ulfah. (2016). "The Impact of ROA, BOPO and FDR to Indonesian Islamic Bank's Mudharabah Deposit Profit Sharing". Etikonomi, Volume 15 No 1.

Ismail. (2011). Manajemen Perbankan: Dari Teori Menuju Aplikasi. Jakarta: Kencana. 44

Indriantoro, Nur., dan Supomo, Bambang. (2013). Metodologi Penelitian Bisnis Untuk Akuntansi \& Manajemen. Yogyakarta: BPFE. 143

Judisseno, Rimsky K. (2005), Perpajakan (Edisi Revisi). Jakarta : Penerbit Gramedia Pustaka Utama.

Kasmir. (2012). Analisis Laporan Keuangan. Jakarta : PT. Raja Grafindo Persada. 50

Kasmir. (2014). Dasar-dasar PerbankanEdisi Revisi, Cetakan kedua belas. Jakarta: Rajawali Pers. 71.

Kasri, A Rahmatina. Kuncoro, Mudrajad \& Suhardjono. (2011). Manajemen Perbankan. BPFE: Yogyakarta.

Mawardi, Wisnu. 2005. "Analisis FaktorFaktor Yang Mempengaruhi Kinerja Keuangan Bank Umum Di Indonesia (Studi Kasus Pada Bank 
Umum Dengan Total Assset Kurang Dari 1 Triliun)". Jurnal Bisnis Strategi, Vol. 14, No. 1, Hal: 83-93, Juli.

Mishkin, Frederic S. (2008). Ekonomi Uang, Perbankan, dan Pasar Keuangan. Edisi 8. Salemba Empat : Jakarta.

Nachrowi, N. Djalal dan Hardius Usman (2006). Pendekatan Populer dan Praktis Ekonometrika untuk Analisis Ekonomi dan Keuangan. Jakarta: LPFE Universitas Indonesia.

Novianto, Abdullah Syakur dan Djumilah Hadiwidjojo. (2013). "Analisis Faktor-faktor yang Mempengaruhi Penghimpunan Deposito Mudharabah Perbankan Syariah di Indonesia". Jurnal Aplikasi Manajemen, Vol. 11 No 4, Desember.

Rivai, Veithzal dan Arviyan Arifin. (2010). Islamic Banking: Sebuah Teori, Konsep, dan Aplikasi. Jakarta: Bumi Aksara. 30

Salomo, M Ronny. (2007). Peranan Perdagangan Internasional Sebagai Salah Satu Sumber Pertumbuhan Ekonomi Indonesia. Dalam Jurnal perdagangan Internasional, parallel session IIId : trade III ( growth \& fdi). Jakarta: Fakultas Ekonomi UI.

Sholihin, Ahmad Ifham. (2010). Buku Pintar Ekonomi Syariah. Jakarta: PT. Gramedia Pustaka Utama.

Sugiyono. (2012). Metode Penelitian Bisnis. Bandung : Alfabeta.

\footnotetext{
Sunariyah. (2011). Pengantar Pengetahuan Pasar Modal, Edisi Keenam. Yogyakarta : UPP AMP YKPN
}

UU Nomor 21 Tahun 2008

Veithzal Rivai dkk. (2007). Bank dan Financial Institution Managemen Conventional \& Syaria System. Jakarta : PT. Raja Grefindo Persada. 413.

\section{PROFIL PENULIS}

Bisri, Lulusan Manajemen FEIS UIN Syarif Hidayatullah Jakarta tahun 2005 kemudian memulai karir di SUCOFINDO tahun 2005-2006 kemudian menjadi senior konsultan di PT Insan Warasindo tahun 2007-2015, General Manager di PT Hasbindo Megah Perkasa 2016-2017, Direktur Program dan Pengembangan BMG Consulting Group 2017-sekarang, Dosen di BSI 2010-sekarang.

Herlin Widasiwi Setianingrum, lahir di Yogyakarta. Menyelesaikan studi S1 Jurusan Bahasa dan Sastra Inggris di Universitas Negeri Jakarta pada tahun 2010, dan Program Pascasarjana Magister Manajemen di Universitas BSI Bandung pada tahun 2015. Aktif sebagai dosen tidak tetap di Akademi Bahasa Asing BSI Jakarta sejak awal tahun 2011. 